\title{
Analysis of Nitrogen Nutrients in Liquid Organic Fertilizers from Wastewater of Rice Washing and Coconut Husks Mixture
}

\author{
*Wardatul Hanifah, Vanny M. A. Tiwow \& Ratman \\ Pendidikan Kimia/FKIP - Universitas Tadulako, Palu - Indonesia 94119 \\ Received 23 December 2019, Revised 28 January 2019, Accepted 24 February 2020 \\ doi: 10.22487/j24775185.2020.v9.i1.pp53-57
}

\begin{abstract}
This study aimed to determine the process of making a liquid organic fertilizer from wastewater of washing rice and coconut husks as well as to determine the amount of nitrogen contained in liquid organic fertilizer. Nitrogen contents were determined using a colorimeter. The results showed that the nutrient content of nitrogen in the liquid organic fertilizer from wastewater of washing rice and coconut husk from fermentation process in a sample of 10 days for a ratio of 1: 3, $1: 1$ and 3:1 was obtained that nitrogen contents were respectively 0.52, 0.41 , and $0.20 \%$. The results of fermentation in a sample of 14 days for a ratio of $1: 3,1: 1$ and 3:1 obtained that nitrogen contents were $0.62,0.49$, and $0.25 \%$.
\end{abstract}

Keywords: Liquid organic fertilizer, wastewater of rice washing, coconut husks, nitrogen $(\mathrm{N})$

\section{Pendahuluan}

Pupuk organik merupakan pupuk yang terbuat dari bahan-bahan organik seperti sisa sayuran, kotoran ternak dan lain sebagainya yang berasal dari mahluk hidup yang telah mati. Pembusukan dari bahan-bahan organik dan mahkluk hidup yang telah mati menyebabkan perubahan sifat fisik dari bentuk sebelumnya. Berdasarkan bentuknya, pupuk organik dibedakan menjadi dua, yaitu pupuk cair dan pupuk padat (Hadisuwito, 2012).

Pupuk organik cair adalah pupuk yang kandungan bahan kimianya dapat memberikan hara yang sesuai dengan kebutuhan tanaman pada tanah (Taufika, 2011). Pupuk organik cair mempunyai beberapa manfaat di antaranya dapat mendorong dan meningkatkan pembentukan klorofil daun dan pembentukan bintil akar pada tanaman leguminosae, sehingga meningkatkan kemampuan fotosintesis tanaman dan penyerapan nitrogen dari udara, dapat meningkatkan vigor tanaman sehingga tanaman menjadi kokoh dan kuat, meningkatkan daya tahan tanaman terhadap kekeringan, cekaman cuaca, dan serangan patogen penyebab penyakit, merangsang pertumbuhan cabang produksi, meningkatkan pembentukan bunga dan bakal buah, mengurangi gugurnya daun, bunga, dan bakal buah (Marpaung, 2014).Sedangkan pupuk organik padat merupakan pupuk yang terbuat dari bahan organik dengan hasil akhir berbentuk padat.

Pupuk organik cair lebih efektif dan efisien jika diaplikasikan pada tumbuhan. Pupuk organik cair berfungsi sebagai perangsang tumbuh pada tanaman. Daun dan batang bisa menyerap secara langsung pupuk yang diberikan melalui stomata atau pori-pori (Sundari dkk., 2014). Keunggulan lain dari pupuk organik cair yaitu dapat merevitalisasi produktivitas tanah, menekan biaya, dan meningkatkan kualitas tanaman (Hadisuwito, 2012).

Nitrogen digunakan oleh mikroorganisme untuk mensintesis protein, dalam tumpukan awal kompos nitrogen akan diubah menjadi $\mathrm{NO}_{3}{ }^{-}$(nitrat) maupun ammonia $\left(\mathrm{NH}_{4}^{+}\right)$sehingga dapat diserap tanah. Kandungan ammonia yang ada di dalam kompos akan meningkat dan selanjutnya akan diubah menjadi senyawa yang mudah diserap tanah (Hardjowigeno, 2003).

Salah satu limbah yang mengandung unsur nitrogen $(\mathrm{N})$, mudah diperoleh, dan dapat digunakan sebagai pupuk organik cair bagi tanaman adalah limbah air cucian beras. Pada proses pencucian, beras biasanya dicuci atau dibilas sebanyak 3 kali sebagai upaya untuk membersihkan beras dari kotoran. Air cucian beras atau sering disebut sebagai leri (bahasa Jawa) berwarna putih susu, hal itu berarti bahwa protein dan vitamin B1 yang banyak terdapat dalam beras juga ikut terkikis (Baning dkk., 2016). Air cucian beras selama ini kurang dimanfaatkan oleh masyarakat umum, padahal air cucian beras banyak mengandung unsur hara yang dibutuhkan oleh tanaman untuk tumbuh. Sejalan dengan hasil penelitian Wulandari dkk., (2013) dapat diketahui bahwa air cucian beras merah dan beras putih mengandung unsur hara nitrogen, phosporus dan kalium secara berturutturut sebanyak $0.015,16.306$ dan $0.02 \%$. Berdasarkan kandungan unsur hara yang telah 
diperoleh pada penelitian sebelumnya, maka limbah air cucian beras terbukti dapat digunakan sebagai pupuk organik cair pengganti pupuk kimia pada beberapa tumbuhan. Limbah ini dapat meningkatkan pertumbuhan akar tanaman selada pada jenis dan kadar air cucian beras yang berbeda (Wardiah dkk., 2014).

Jenis pupuk organik cair selain limbah air cucian beras ada juga sabut dari buah kelapa. Bagian dari buah kelapa yang sering diambil untuk dimanfaatkan sebagai bahan masakan adalah daging buah dan air kelapanya, sehingga sabut kelapa dibuang begitu saja dan kurang dimanfaatkan. Oleh karena itu, studi pemanfaatan sabut kelapa perlu dilakukan agar lebih memiliki nilai guna, sehingga dapat mereduksi jumlah sabut kelapa dalam timbunan sampah (Waryanti dkk., 2013). Kandungan unsur hara yang terdapat dalam sabut kelapa, yaitu: air $53.83 \%, \mathrm{~N} 0.28 \%$ ppm, P 0.1 ppm, K 6.726 ppm, Ca 140 ppm, dan Mg 170 ppm (Jamilah dkk., 2013). Sejalan dengan hasil penelitian Susanti (2016) dapat diketahui bahwa kandungan unsur hara dari penambahan sabut kelapa pada pupuk organik cair mengandung unsur hara Nitrogen, Phospor dan Kalium secara berturutturut sebanyak $0.21 \%, 503.60 \mathrm{ppm}$ dan 538.70 ppm.

Standar pupuk organik cair menurut Peraturan Menteri tahun 2011 tentang "Pupuk Organik, Pupuk Hayati dan Pembenah Tanah" kadar Nitrogen $(\mathrm{N})$ minimal untuk pupuk organik cair sebesar 3-6\%, Phospor (P) sebesar 3-6\% dan Kalium (K) sebesar 3-6\%.

Tulisan ini dimaksudkan untuk memaparkan analisis unsur hara nitrogen pada pupuk organik cair campuran air cucian beras dan sabut kelapa.

\section{Metode}

Alat yang digunakan dalam penelitian ini yaitu wadah, pipet tetes, neraca digital, colorimeter, alat destruksi Kjeldahl, gelas kimia, lumpang dan alu dan tabung reaksi.

Bahan yang digunakan pada penelitian ini yaitu limbah air cucian beras, sabut kelapa, gula merah, air bersih, bakteri EM4 (Merck), larutan $\mathrm{H}_{2} \mathrm{SO}_{4}$ pekat (Merck), aquades, dan tablet Kjeldahl $($ Merck).

\section{Pembuatan Pupuk Organik Cair}

Pembuatan pupuk organik cair dari limbah cucian air beras diawali dengan mencuci beras sebanyak 1 Liter dengan air bersih 2 Liter kemudian air cucian beras pertama diambil sebanyak 1,5 Liter. Setelah itu untuk pembuatan pupuk organik cair dari limbah sabut kelapa diawali dengan memotong-motong sabut kelapa tersebut hingga menjadi potongan yang lebih kecil. Kemudian direndam dengan 1,5 Liter air selama dua hari. Setelah itu membagi kedua bahan masing-masing menjadi 3 sampel. Masing-masing bahan yang telah dibuat kemudian dicampurkan dengan perbandingan 1:3, 1:1 dan 3:1 dengan jumlah hari fermentasi yang berbeda. Setelah itu ditambahkan dengan bakteri EM- $45 \mathrm{~mL}$ dan larutan gula merah $10 \mathrm{~mL}$. Selanjutnya wadah ditutup rapat hingga udara tidak bisa masuk dan kemudian di fermentasi selama 10 dan 14 hari.

\section{Analisis Sampel Kadar Nitrogen (N)}

$10 \mathrm{~mL}$ sampel hasil fermentasi dimasukkan ke dalam labu Kjeldahl, kemudian ditambahkan dengan $10 \mathrm{~mL} \mathrm{H}_{2} \mathrm{SO}_{4}$ pekat dan satu sendok spatula tablet Kjeldahl. Selanjutnya didestruksi (dipanaskan) sampai mendidih dan larutan menjadi jernih. Setelah didestruksi larutan dibiarkan beberapa saat sampai dingin. Selanjutnya larutan jernih yang telah didestruksi diencerkan sampai volume $100 \mathrm{~mL}$. Sampel yang telah diencerkan kemudian diambil masing-masing sebanyak $10 \mathrm{~mL}$ dan dimasukkan ke dalam 3 buah tabung reaksi untuk dianalisis menggunakan alat colorimeter (Nirmala, dkk., 2015).

\section{Hasil dan Pembahasan}

Proses fermentasi akan terjadi lebih cepat pada lingkungan kedap udara (anaerob) dimana akan mengasilkan sejumlah senyawa organik seperti asam laktat, asam nukleat, bihormon, dan lain sebagainya yang mudah diserap oleh akar tanaman serta melindungi tanaman dari hama penyakit (Natsi, dkk., 2016). Air pada proses fermentasi berfungsi sebagai media untuk pertumbuhan bakteri selain berfungsi sebagai pelarut (Nurhayati, 2006). Berikut reaksi yang terjadi pada proses anaerobik saat pembuatan pupuk organik cair (Sundari dkk., 2014):

$$
\text { Bahan Organik } \stackrel{\text { Mikroorganisme }}{\longrightarrow} \mathrm{CH}_{4}+\text { hara + humus }
$$

Sampel pada awal pembuatan limbah air cucian beras dan limbah sabut kelapa keduanya berwarna kuning dan berbau. Semakin lama proses fermentasi dilakukan maka sampel semakin berwarna coklat dan memiliki bau yang khas seperti alkohol. Berdasarkan hasil pengamatan fisik pada larutan mikro organisme lokal (MOL) setelah difermentasi terjadi perubahan warna pada larutan dari kuning sebelum fermentasi dan menjadi kecoklatan setelah dilakukan fermentasi, perubahan warna pada kedua MOL hanya diamati secara visual. Terdekomposisinya bahan-bahan organik yang disebabkan oleh aktivitas bermacam-macam mikroorganisme yang akan menyebabkan terjadinya perubahan warna. Sementara perubahan aroma pada kedua sampel menjadi bau khas seperti alkohol dikarenakan dimulainya proses fermentasi. Mikroorganisme yang tumbuh dan berkembang pada suatu bahan dapat menyebabkan berbagai perubahan pada fisik maupun komposisi kimia, seperti adanya perubahan warna, pembentukan endapan, kekeruhan, pembentukan gas, dan bau asam. Fermentasi dapat terjadi karena ada aktivitas mikroorganisme, penyebab fermentasi pada substrat organik yang sesuai, proses ini dapat menyebabkan perubahan sifat bahan tersebut. Lama fermentasi 
dipengaruhi oleh faktor-faktor yang secara langsung maupun tidak langsung berpengaruh terhadap proses fermentasi. Waktu fermentasi MOL berbedabeda antara satu jenis bahan MOL dengan yang lainnya. Waktu fermentasi ini berhubungan dengan ketersediaan makanan yang digunakan sebagai sumber energi dan metabolisme dari mikroorganisme. Mikroorganisme pada MOL cenderung menurun setelah hari ke-14. Hal ini berhubungan dengan ketersediaan makanan dalam
MOL. Proses fermentasi yang lama menyebabkan cadangan makanan akan berkurang karena dimanfaatkan oleh mikrobia di dalamnya (Purwasasmita, 2009).

\section{Kadar Nitrogen}

Berdasarkan studi yang telah dilakukan, dapat diketahui kadar nitrogen dari pupuk organik cair dari limbah air cucian beras dan sabut kelapa disajikan pada Tabel 1.

Tabel 1. Kadar unsur nitrogen pada pupuk organik cair dari limbah air cucian beras dan sabut kelapa

\begin{tabular}{|c|c|c|c|c|c|c|}
\hline \multirow{2}{*}{ No } & \multirow{2}{*}{ Lama Fermentasi } & \multirow{2}{*}{$\begin{array}{l}\text { Perbandingan Volume Sampel } \\
(\mathrm{mL})\end{array}$} & \multicolumn{3}{|c|}{ Kadar Nitrogen (\%) } & \multirow{2}{*}{ Rata-rata } \\
\hline & & & I & II & III & \\
\hline \multirow{3}{*}{1.} & \multirow{3}{*}{10 hari } & $\begin{array}{l}1: 3 \\
\text { (air cucian beras : sabut kelapa) }\end{array}$ & 0,52 & 0,52 & 0,52 & 0,52 \\
\hline & & $\begin{array}{l}1: 1 \\
\text { (air cucian beras : sabut kelapa) }\end{array}$ & 0,40 & 0,42 & 0,42 & 0,41 \\
\hline & & $\begin{array}{l}3: 1 \\
\text { (air cucian beras : sabut kelapa) }\end{array}$ & 0,20 & 0,20 & 0,20 & 0,20 \\
\hline \multirow{3}{*}{2.} & \multirow{3}{*}{14 hari } & $\begin{array}{l}1: 3 \\
\text { (air cucian beras : sabut kelapa) }\end{array}$ & 0,62 & 0,63 & 0,63 & 0,62 \\
\hline & & $\begin{array}{l}1: 1 \\
\text { (air cucian beras : sabut kelapa) }\end{array}$ & 0,49 & 0,49 & 0,49 & 0,49 \\
\hline & & $\begin{array}{l}3: 1 \\
\text { (air cucian beras : sabut kelapa) }\end{array}$ & 0,24 & 0,26 & 0,26 & 0,25 \\
\hline
\end{tabular}

Tabel 1 menunjukkan kadar nitrogen yang diperoleh pada pupuk organik cair dari limbah air cucian beras dan sabut kelapa.

Penentuan kadar nitrogen $(\mathrm{N})$ pada sampel pupuk organik cair dari limbah air cucian beras dan limbah sabut kelapa dilakukan dengan menggunakan metode Kjeldahl. Prosedur Kjeldahl memiliki tiga tahap yaitu penghancuran (destruksi), netralisasi atau distilasi, dan yang terakhir yaitu titrasi. Studi ini hanya dilakukan pada tahap destruksi saja, hal ini karena penentuan nitrogennya dilakukan dengan menggunakan alat colorimeter.

Analisis nitrogen secara kuantitatif kadar nitrogen pada penelitian ini menggunakan colorimeter. Kadar nitrogen yang diperoleh pada pupuk organik cair dari limbah air cucian beras dan limbah sabut kelapa untuk perbandingan 1:3 sebanyak $0.52 \%$, perbandingan 1:1 sebanyak $0.41 \%$, dan untuk perbandingan $3: 1$ sebanyak $0.20 \%$ untuk fermentasi selama 10 hari. Perbandingan 1:3 sebanyak $0.62 \%$, perbandingan $1: 1$ sebanyak $0.49 \%$, dan untuk perbandingan $3: 1$ sebanyak $0.25 \%$ untuk fermentasi selama 14 hari. Berdasarkan hasil tersebut, bahwa terjadi peningkatan kadar nitrogen berdasarkan lama waktu fermentasinya. Peningkatan kadar nitrogen karena adanya proses penguraian bahan organik pada saat fermentasi oleh mikroorganisme pengurai. Menurut Sundari (2012), larutan EM-4 mengandung mikroorganisme yang kurang lebih jumlahnya 80 genus. Kenaikkan kadar nitrogen disebabkan oleh adanya dekomposisi penguraian protein serta adanya reaksi amonifikasi yaitu proses pembentukan ommonium. Peningkatan nitrogen diakhir proses juga disebabkan adanya proses amonifikasi, yaitu proses pembentukan ammonium dari bentuk teroksidasinya yaitu nitrit.

Kadar nitrogen dengan volume sabut kelapa yang besar memiliki kadar nitrogen yang lebih tinggi dibandingkan air cucian beras. Hal ini dapat dilihat dari perbandingan volume sampel yang digunakan. Semakin besar volume dari sabut kelapa tersebut, maka semakin tinggi pula kadar nitrogennya. Hal ini sejalan dengan penelitian Susanti (2016) bahwa pupuk organik cair daun kelor dengan penambahan sabut kelapa mengandung unsur hara $\mathrm{N}, \mathrm{P}, \mathrm{K}$ dengan nitrogen sebanyak $0.21 \%$, serta penelitian Wulandari, (2013) pengaruh air cucian beras merah dan beras putih terhadap pertumbuhan dan hasil selada (Lactuca sativa L.) mengandung unsur hara N, P dan $\mathrm{K}$ dengan nitrogen sebanyak $0.015 \%$. Dari penelitan sebelumnya dapat dilihat bahwa kadar nitrogen dari sabut kelapa lebih besar dibandingkan dengan air cucian beras.

Mikroba memecah senyawa karbon sebagai sumber energi dan menggunakan nitrogen untuk disintesis protein. Perubahan nilai nitrogen total pada tiap reactor tidak sama akibat kecepatan mikroba yang mengurai bahan fermentasi berbedabeda (Purba dkk., 2013). Sebagian dari nitrogen total dapat terikat sebagai nitrogen organik, yaitu dalam bahan-bahan berprotein. Mikroorganisme selain merombak bahan organik menjadi lebih sederhana, juga menggunakan bahan organik untuk aktifitas metabolisme hidupnya (Dwicaksono, dkk., 2013).

Fungsi dari penambahan larutan gula merah yaitu sebagai nutrisi mikroorganisme dan sebagai bahan tambahan untuk mengasilkan pupuk yang 
berkualitas, fungsi penambahan bakteri EM4 (efektivitas mikroorganisme) yaitu untuk mempercepat proses fermentasi, meningkatkan pertumbuhan serta meningkatkan kualitas dan kuantitas produksi tanaman. EM4 merupakan kultur campuran dari mikroorganisme menguntungkan yang bermanfaat untuk meningkatkan kesuburan tanah dan tanaman, EM4 juga bermanfaat untuk memfermentasi limbah organik menjadi pupuk organik (Siboro dkk., 2013). Setelah itu dilakukan proses fermentasi. Proses fermentasi bertujuan untuk menguraikan bahan organik yang dapat dimetabolisme atau didegradasi oleh mikroorganime, sehingga nutrisi yang dihasilkan akan dalam bentuk protein, asam amino, enzim, dan vitamin yang berguna untuk pertumbuhan tanaman (Pangnakorn dkk., 2010).

\section{Kesimpulan}

Hasil analisis kadar unsur hara kandungan unsur hara Nitrogen pada pupuk organik cair dari limbah air cucian beras dan sabut kelapa hasil fermentasi pada sampel 10 hari untuk perbandingan 1:3, 1:1 dan 3:1 diperoleh kadar Nitrogen secara berturut-turut sebesar $0.52 \%, 0.41 \%$, dan $0.20 \%$. Hasil fermentasi pada sampel 14 hari untuk perbandingan 1:3, 1:1 dan 3:1 diperoleh kadar Nitrogen secara berturut-turut sebesar $0.62 \%$, $0.49 \%$, dan $0.25 \%$.

\section{Ucapan Terima kasih}

Penulis mengucapkan terima kasih kepada Nurbaya dan Husniah Muchtar yang telah memberikan bimbingan dan masukan dalam menyelesaikan penelitian ini.

\section{Referensi}

Baning, C., Rahmatan, H. \& Supriatno. (2016). Pengaruh pemberian air cucian beras merah terhadap pertumbuhan vegetatif tanaman lada (Piper nigrum L.). Jurnal Ilmiah Mahasiswa Pendidikan Biologi, 1(1), 1-9.

Dwicaksono, M. R. B., Suharto, B., \& Susanawati, L. D. (2015). Pengaruh penambahan effective microorganism pada limbah cair industri perikanan terhadap kualitas pupuk organik cair. Jurnal Sumberdaya Alam dan Lingkungan, 1(1), 7-11.

Hadisuwito, S. (2012). Membuat pupuk organik cair. Jakarta: Agromedia Pustaka.

Hardjowigeno, S. 2003. Ilmu tanah. Jakarta: Akademika Pressindo.

Jamilah, Napitupulu, Y., \& Marni, Y. (2013). Peranan gulma chromoleana odorata dan sabut kelapa sebagai bahan baku pupuk organik cair menggantikan pupuk kalium untuk pertumbuhan dan hasil padi ladang. Padang: Fakultas Pertanian Universitas Taman Siswa Padang.
Marpaung, A. E., Karo, B., \& Tarigan, R. (2014). Pemanfaatan pupuk organik cair dan teknik penanaman dalam peningkatan pertumbuhan dan hasil kentang. Jurnal Hortikultura, 24(1), 49-55.

Natsi, N. A., Kilwouw, C., \& Salim. (2016). Penerapan teknologi pembuatan pupuk organik dalam pengolahan limbah pasar mardika ambon. Journal Biology Science and Education, 5(1), 12-22.

Nirmala., Tiwow, V. M. A., \& Suherman. (2015). Adsorpsi ion tembaga $(\mathrm{Cu})$ dan ion besi $(\mathrm{Fe})$ dengan menggunakan arang hayati (biocharcoal) kulit pisang raja (Musa sapientum). Jurnal Akademika Kimia, 4(4), 189-196.

Nurhayati, S. (2006). Kajian pengaruh kadar gula dan lama fermentasi terhadap kualitas nata de soya. Jurnal Matematika Sains dan Teknologi, 7(1), 40-47.

Pangnakorn, U., Watanasorn, S., Kuntha, C., \& Chuenchooklin. (2010). Effects wood vinegar and fermented liquid organic fertilizer on soybean (Srisamrong L) cultivanted under drought conditions. Journal International Society for Southeast Asian Agicultural Sciences, 16(2), 67-73.

Purba, R., Sutrisno, E., \& Sumiyati, S. (2013). Pengaruh penambahan limbah udang pada pupuk cair dari fermentasi urin sapi terhadap unsur hara makro. Jurnal Teknik Lingkungan, 2(3), 1-8.

Purwasasmita, M. (2009). Mikroorganisme local sebagai pemicu siklus kehidupan dalam bioreactor tanaman. Seminar Nasional Teknik Kimia Indonesia, 19-20.

Siboro, E. S., Surya, E., \& Herlina, N. (2013). Pembuatan pupuk cair dan biogas dari campuran limbah sayuran. Jurnal Teknik Kimia USU, 2(3), 40-43.

Sundari, E., Sari, E., \& Rinaldo, R. (2012). Pembuatan pupuk orgaik cair menggunakan bioaktivator boisca dan EM-4. Prosiding SNTK Topi ( $p p$. 93-97). Pekanbaru.

Sundari, I., Maruf, W. F., \& Dewi, E. N. (2014). Pengaruh penggunaan biovaktor em 4 dan penambahan tepung ikan terhadap spesifikasi pupuk organik cair rumput laut (Gracilaria sp.). Jurnal Pengolahan dan Bioteknologi Hasil Perikanan, 3(3), 88-94.

Susanti, S. (2016). Pengaruh pupuk organik cair kombinasi daun kelor dan sabut kelapa terhadap pertumbuhan tanaman jagung. Skripsi Tidak Diterbitkan. Surakarta: Universitas Muhammadiyah Surakarta. 
Taufika, R. (2011). Pengujian beberapa dosis pupuk organik cair terhadap pertumbuhan dan hasil tanaman wortel (Doucus carota L). Jurnal Tanaman, 1(2), 1-10.

Wardiah., Linda. \& Rahmatan, H. (2014). Potensi limbah air cucian beras sebagai pupuk organik cair pada pertumbuhan pakchoy (Brassica rapa L.). Jurnal Biologi Edukasi, 6(1), 34-38.

Waryanti, A., Sutrisno, E., \& Sudarno. (2013). Studi pengaruh penambahan sabut kelapa pada pembuatan pupuk cair dari limbah air cucian ikan terhadap kualitas unsur hara makro (CNPK). Jurnal Teknologi, 8(3), 4041.

Wulandari, C. G. M., Muhartini, S., \& Trisnowati, S. (2013). Pengaruh air cucian beras merah dan beras putih terhadap pertumbuhan dan hasil selada (Lactuca sativa L.). Vegetalika, 1(2), 24-35.

Yulianingsih, R. (2017). Pengaruh air cucian beras terhadap pertumbuhan dan hasil terung ungu (solanum melongena l.). Piper, 24(13), 27-38. 